\title{
PENGARUH PELATIHAN SKALA KESEIMBANGAN, MATA, WAJAH, TANGAN, BICARA (KEM-WATABI) TERHADAP KEMAMPUAN PSIKOMOTOR KADER POSYANDU LANSIA DALAM SKRINING STROKE
}

\author{
Muhammad Taukhid $^{1)}$, Andika Siswoaribowo ${ }^{2)}$, dan Dina Zakiyyatul Fuadah ${ }^{3)}$ \\ ${ }^{1}$ Prodi Pendidikan Profesi Ners, STIKES Karya Husada Kediri \\ ${ }^{2,3}$ Prodi Sarjana Keperawatan, STIKES Karya Husada Kediri \\ 1,2,3 Jl. Sukarno Hatta No. 7, Pare, Kediri, 64225 \\ E-mail : mtaukhid@stikes-khkediri.ac.id ${ }^{1}$, andikasiswoaribowo@stikes-khkediri.ac.id ${ }^{2)}$,dinazakiyyatul@stikes- \\ khkediri.ac.id ${ }^{3)}$
}

\begin{abstract}
ABSTRAK
Penelitian ini ditujukan untuk mengetahui pengaruh pelatihan skala keseimbangan, mata, wajah, tangan dan bicara (KEMWATABI) terhadap kemampuan psychomotor kader posyandu lansia dalam melakukan skrining stroke di desa Darungan, Pare, Kediri. Penelitian menggunakan desain pre eksperimental dengan pendekatan one group pre-post-test design. Populasi penelitian ini adalah kader posyandu lansia sebanyak 24 kader, melalui teknik purposive sampling didapatkan subjek penelitian sebanyak 16 kader. Subjek diberikan pelatihan mulai dari sesi 1 sampai 6 yang terdiri atas kegiatan pemberian materi, demonstrasi, praktik skrining stroke pada lansia. Instrumen yang digunakan untuk mengukur kemampuan kader adalah lembar observasi. Analisis data penelitian menggunakan Wilcoxon Signed Rank test. Hasil penelitian menunjukkan seluruh subjek (100\%) memiliki kemampuan psychomotor dalam tingkatan tidak mampu pada pretest, hasil post-test menunjukkan 13 kader $(81,25 \%)$ berada pada tingkatan mampu dan 3 kader $(18,75 \%)$ berada pada tingkatan cukup mampu. Terdapat pengaruh yang signifikan pelatihan skala KEM-WATABI terhadap kemampuan kader posyandu lansia dalam skrining stroke $\left(\mathrm{p}_{\mathrm{v}}=0,001<\alpha=0,005\right)$. Metode pelatihan yang diberikan memberikan pengalaman praktik dengan simulasi skrining stroke secara langsung pada lansia sehingga subjek mendapatkan gambaran konkrit tahapan skrining stroke, dan meningkatkan kemampuan psychomotor.
\end{abstract}

Kata Kunci: Stroke, skala KEM-WATABI, Kader Posyandu, Lansia, Kemampuan Psychomotor.

\section{PENDAHULUAN}

Penyakit neurologi menjadi salah satu penyebab kecacatan dan kematian di seluruh dunia. Peningkatan populasi penduduk dunia dan meningkatnya angka harapan hidup dalam beberapa tahun ini mengindikasikan bahwa banyak populasi yang mencapai usia lanjut, dimana pada kelompok usia ini yang paling sering terjadi kasus penyakit neurologi seperti stroke dan gangguan komunikasi. Angka kecacatan yang disebabkan oleh penyakit neurologi di seluruh dunia pada tahun 2015 berkisar antara 229 - 274 juta kasus, sedangkan angka kematiannya rata-rata sebanyak 9,4 juta kasus.

Insiden stroke di seluruh dunia mencapai 15 juta kasus, dimana sepertiga kasus mengalami kematian dan sepertiganya mengalami kecacatan permanen. Stroke sendiri menjadi penyebab dari $10 \%$ angka kematian secara global, angka kejadian tertinggi terjadi di Cina, Afrika dan Amerika Serikat sebanyak 19,9\% kasus (Mutiarasari, 2019). Kejadian stroke di negara berkembang termasuk di Indonesia semakin meningkat. Tahun 2013, angka kejadian stroke pada kisaran 7 dari 1000 kehidupan, namun pada 2018 meningkat menjadi 10, 9 per 1000 penduduk di Indonesia. Stroke menjadi penyebab utama pada $11,8 \%$ kematian dan kecacatan, serta menjadi beban penyakit maupun ekonomi (Arif $d k k ., 2019)$.

Secara umum stroke di makna sebagai penyakit yang timbul akibat adanya gangguan pada pembuluh darah di otak. Berdasarkan penyebabnya stroke dibagi menjadi dua jenis, yaitu; Haemorrhagic adalah stroke yang terjadi akibat pecahnya pembuluh darah di otak, dan Ischemia yaitu serangan stroke yang terjadi akibat adanya sumbatan pada pembuluh darah di otak, (Ojaghihaghighi, $d k k$, 2017). Meskipun secara diagnostik dapat dibedakan, namun kedua jenis stroke ini akan memunculkan gejala klinis awal yang relatif sama yaitu kelainan pada sistem neurologi seperti gangguan terhadap kemampuan keseimbangan, gangguan bicara, kelemahan otot dan sebagainya.

Tanda dan gejala stroke adalah yang umum adalah hemiparesis, gangguan sensorik satu sisi tubuh, hemianopia atau buta mendadak, diplopia, vertigo, disfagia, disartria, ataksia, dan penurunan kesadaran yang terjadi secara mendadak (Setianingsih $d k k$., 2019).

Perkembangan metode penanganan stroke di rumah sakit sudah cukup pesat, mulai dari terapi, tempat perawatan hingga rehabilitasi, dan hasilnya menunjukkan 
tren penurunan angka kematian akibat stroke pada fase akut. Namun yang perlu diperhatikan juga adalah gejala sisa yang ditimbulkan stroke berdampak cukup luas dalam aspek kehidupan pasien, seperti aspek fisik, emosional, psikologis, kognitif dan juga sosial (Bariroh $d k k$., 2016). Pasien stroke yang mampu melalui fase akut, dapat mengalami kecacatan dalam jangka panjang, dan menyebabkan pasien membutuhkan bantuan dari keluarga dalam menjalankan aktivitas sehari-hari. Kecacatan yang dialami pasien bukan hanya secara fisik yang menghambat mobilitas nya, namun kecacatan juga bisa terjadi secara psikosial yang menghambat pasien dalam melakukan sosialisasi dengan lingkungan di sekitarnya (Rahman $d k k$., 2017).

Penanganan stroke yang baik harus memperhatikan golden periode atau periode terbaik dimana dampak kerusakan pada sel saraf otak yang ditimbulkan stroke dapat diminimalkan, periode terbaik ini adalah 4,5 jam sejak awal kejadian (Prabhakaran \& Ruff, 2015). Jika ada pasien stroke mendapatkan penanganan diluar golden period, maka kerusakan neurologis yang dialami pasien akan bersifat permanen.

Angka kedatangan pasien stroke di fasilitas kesehatan dalam golden periode masih kurang, sebagian masyarakat datang ke rumah sakit setelah tidak adanya perbaikan dari gejala dalam waktu tertentu atau gejala yang muncul semakin memburuk. Berdasarkan pengamatan kedatangan di rumah sakit, dari 110 pasien stroke di lima rumah sakit daerah di DKI Jakarta, didapatkan bahwa hanya 27 pasien $(24,5 \%)$ yang datang dalam kurun waktu $\leq 3$ jam, sisanya datang $>3$ jam setelah onset kejadian dengan presentasi terbanyak yakni $41,8 \%$ datang setelah 1 hari dari onset kejadian stroke (Prasetyo, 2018). Selain disebabkan letak geografis, sarana transportasi, ketersediaan fasilitas kesehatan, faktor budaya juga turut menentukan dalam pengambilan keputusan. Lansi yang ada di Indonesia kebanyakan tinggal bersama dengan keluarganya, hal ini menjadi salah satu nilai positif yang dapat dimanfaatkan untuk penanganan stroke pre hospital. Pemahaman keluarga atau orang terdekat dengan lansia yang memiliki risiko stroke menjadi kunci penting dalam penanganan awal ketika serangan stroke terjadi.

Terdapat beberapa cara atau alat ukur yang dapat digunakan untuk mengetahui tanda dan gejala stroke, diantaranya skala face arm speech time (FAST), Cincinnati pre hospital stroke scale (CPSS), prehospital ambulance stroke test (PreHAST), recognition of stroke in the emergency room (ROSIER). Diantara cara tersebut, skala FAST menjadi yang paling banyak dikenal dan digunakan untuk skrining stroke karena cukup singkat dan cepat. Namun, menurut beberapa ahli, skala tersebut perlu dilakukan revisi dengan menambahkan item keseimbangan (balance)dan lapang pandang mata (eyes), dimana kedua indikator ini telah banyak diungkapkan oleh pasien sebagai gejala yang dirasakan saat serangan stroke. Oleh karena itu, balance, eyes, face, arm, speech and time (BE-FAST Scale) yang melengkapi item yang masih belum ada pada skala FAST (Aroor $d k k$., 2017).

Penambahan item keseimbangan ini dianggap penting, karena telah ditemukan gejala ini pada pasien yang mengalami serangan stroke pertama maupun serangan ulang. Sesuai dengan alur fisiologis nya, koordinasi tangan dan kaki dikendalikan oleh jaringan saraf yang kompleks, kemampuan seseorang dalam mempertahankan keseimbangan akan dipengaruhi oleh sirkuit sensorik yang mengontrol penglihatan, kepekaan tubuh seseorang untuk berdiri di ruangan dan fungsi optimal dari sistem vestibular (Wlassoff, 2015). Ketidakmampuan seseorang dalam mempertahankan keseimbangan, dapat diartikan bahwa ada kemungkinan kerusakan pada sirkuit otak. Gangguan keseimbangan pada pasien dengan gangguan pembuluh darah kecil di otak, dapat diuji dengan menggunakan One-Leg Standing Time (OLST). Penderita diminta untuk memilih kaki terkuat untuk berpijak, sementara kaki yang lain diangkat selama 20 detik. Ketika satu kaki telah diangkat, penghitungan waktu dimulai dan dihentikan ketika kaki telah jatuh atau hitungan telah selesai. Tes dilakukan dua kali, dimana waktu terlama digunakan sebagai acuan untuk menentukan hasil pemeriksaan (Tabara $d k k$., 2015).

Kehilangan atau menurunnya kemampuan lapang pandang mata merupakan dampak yang juga sering ditimbulkan oleh stroke. Dampak ini dapat terjadi melalui beberapa cara, tergantung dimana tepatnya kerusakan area otak akibat stroke. Terdapat empat masalah gangguan penglihatan utama yang timbul akibat stroke (Rowe, 2016), yaitu : kehilangan lapang pandang, masalah pergerakan mata, masalah pengolahan visual, dan masalah penglihatan lainnya. Kehilangan lapang pandang dapat diartikan sebagai kehilangan bagian dari area pandangan atau kemampuan mata memandang, yang dapat diakibatkan oleh kerusakan bagian otak akibat stroke. Secara fisik mata masih dapat bergerak, namun otak tidak dapat memproses gambar yang dihasilkan oleh pandangan. Ketika seseorang mengalami kehilangan lapang pandang pada mata dengan sisi yang sama dengan yang mengalami kelemahan fisik, dinamakan dengan "Homonymous"

Jenis kehilangan lapang pandang yang sering dialami oleh penderita stroke adalah homonymous hemianopia, dimana mata kanan atau kiri mengalami kehilangan bidang visualnya. Sementara jenis yang jarang ditemukan adalah Skotoma, dimana mata kanan atau kiri mengalami kehilangan seberkas kecil dari bidang visualnya. Seringkali gangguan penglihatan ini diartikan adanya kehilangan lapang pandang pada satu sisi mata, padahal yang terjadi sebenarnya adalah kehilangan lapang pandang dari Sebagian kecil lapang pandang mata kanan atau kiri saja.

Sebagai gambaran ilustrasi untuk mengetahui adanya kehilangan lapang pandang, apabila seseorang mengalami hemianopia pada mata kanan, maka orang tersebut tidak akan mampu untuk melihat apa yang ada 
pada sisi sebelah kanan dari tangan kanannya, atau tidak dapat berkomunikasi efektif dengan orang yang berada pada sisi mata yang mengalami gangguan. Namun, ketika orang tersebut menolehkan kepala ke kanan dan melihat lurus, barulah dapat melihat benda atau orang yang ada dalam bidang visualnya. Hal ini terjadi bukan karena kerusakan pada mata, namun karena adanya gangguan proses visualisasi di otak (Howard \& Rowe, 2018).

Ketidaksimetrisan wajah juga menjadi ciri yang khas dari penyakit stroke. Pada pasien stroke, seringkali dijumpai wajah area bagian atas masih simetris, namun bagian bawah asimetris. Ini terjadi karena adanya persaraf ganda di wajah bagian atas, sehingga apabila tidak berfungsi salah satu, maka otot yang lain masih dapat mempertahankan simetris nya.

Wajah memiliki otot-otot yang pergerakannya dikendalikan oleh nerves facials dan terbagi menjadi dua bagian besar, yakni saraf wajah kanan yang mengontrol semua otot di sisi kanan, dan saraf wajah kiri yang mengontrol seluruh otot di bagian kiri. Saraf wajah berasal dari batang otak (Pons Serebri) dan akan membawa serat saraf menuju otot ekspresi wajah. Seratserat saraf wajah ini berasal dari korteks motorik kedua hemisphere otak. Strip korteks motoric dapat dipecah menjadi serat tambahan yang akan masuk pada otot pada bagian wajah atas yang mengatur penutupan mata dan Gerakan dahi, dan juga akan masuk pada bagian otot bawah yang mengatur otot wajah di bagian bawah, termasuk mulut.

Serat saraf yang mengatur bagian bawah wajah, bergerak dari korteks ke batang otak, di batang otak serat ini akan menyeberang ke saraf wajah yang berlawanan atau kontra lateral. Sementara, saraf yang mengatur bagian wajah atas akan mengambil jalur yang sedikit berbeda, sebagian menyeberang ke saraf wajah kontra lateral dan sebagian akan tetap di sisi yang sama dan berkontribusi pada saraf wajah ipsilateral. Oleh karena itu, mata dan dahi akan menerima per-saraf dari kedua hemisphere, sedangkan wajah bagian bawah akan menerima dari belahan kontra lateral (Hal Blumenfeld, 2010). Pemahaman mengenai sumber pergerakan saraf ini penting ketika kita menilai kelemahan pada area wajah. Pada kasus stroke iskemik akut, lesi yang merusak korteks motorik akan melemahkan bagian bawah wajah kontra lateral saja. Sementara, otot pada bagian wajah atas akan tetap dipertahankan kedua sisi, karena adanya per-saraf ganda di area wajah atas. Mekanisme kerja ini memunculkan gejala senyum yang lemah, namun masih dapat menutup mata dengan rapat dan mengerutkan dahi secara simetris.

Pola ini dikenal dengan Central Facial Weakness, karena disebabkan oleh cedera pada korteks serebral, yang merupakan bagian dari system saraf pusat (Loomis. Pemeriksaan yang dapat dilakukan untuk mengetahui adanya tanda dan gejala stroke di wajah bisa dengan cara mengajak atau meminta orang yang dicurigai mengalami stroke untuk tersenyum. Perhatikan apakah wajahnya tampak tidak sama/tidak simetris. Orang yang terkena stroke, wajahnya akan menjadi asimetris atau perot, tetapi masih dapat mengerutkan dahi dan menutup mata secara simetris.

Kelemahan pada otot tangan terjadi akibat hemiparesis area otak, sisi mana yang mengalami hemiparesis sangat tergantung dari sisi otak mana yang mengalami kerusakan. Hemiparesis ini dapat bersifat kontra lateral, artinya kelemahan otot pada salah satu sisi tubuh ini diakibatkan karena gangguan sisi otak yang berlawanan. Hemiparesis ini berbeda dengan hemiplegia, pasien yang mengalami paresis atau paralisis masih bisa menggerakkan otot, namun lemah. Sementara pada pasien yang mengalami hemiplegia artinya mengalami kelumpuhan pada salah satu sisi tubuh, otot sudah tidak mampu untuk digerakkan. Ajak orang yang mengalami stroke untuk mengangkat kedua lengannya lurus ke depan dan menahannya selama 10 detik dengan mata tertutup (Aroor $d k k$., 2017). Pemeriksa dapat mengamati apakah orang tersebut hanya dapat mengangkat dan/atau menahan satu lengan saja ataukah dapat mengangkat keduanya tetapi salah satu terlihat lemah atau turun. Orang yang terkena stroke, salah satu lengan atau tungkainya akan mengalami kelemahan atau kelumpuhan.

Tanda dan gejala stroke yang juga sering dikeluhkan oleh orang yang menderita stroke adalah adanya gangguan komunikasi (Saengsuwan $d k k$., 2017). Cara untuk melakukan identifikasi gangguan komunikasi dengan mengajak orang yang dicurigai mengalami stroke untuk mengulang beberapa kalimat. Selama berkomunikasi, amati apakah orang tersebut mampu berbicara jelas atau terdengar cadel dan pelo. Orang yang terkena serangan stroke akan mengalami gangguan bicara, salah satunya pengucapan menjadi cadel atau tidak jelas.

Skala stroke BE-FAST yang tersedia saat ini secara resmi adalah dalam edisi bahasa Inggris, dan istilah yang ada di dalamnya cenderung menggunakan istilah medis. Penerapan skala ini langsung ke masyarakat akan terkendala terkait pemahaman bahasa yang digunakan, karena tidak semua masyarakat mampu memahami istilah dalam bahasa inggris maupun bahasa medis dengan baik. Metode lain yang lebih sederhana juga telah di kenal oleh Kementerian Kesehatan RI yaitu menggunakan slogan "SeGeRa Ke RS" yang merupakan singkatan dari senyum tidak simetris, gerakan sebelah tubuh melemah tiba-tiba, bicara tiba-tiba pelo, kebas atau kesemutan separuh tubuh, rabun atau hilang lapang pandang pada salah satu sisi mata, dan sakit kepala yang terjadi secara mendadak. Meskipun secara istilah mudah diingat, namun kelemahan dari slogan ini juga belum dilengkapi dengan langkah-langkah pemeriksaan dan lembar dokumentasi nya.

Teknik yang mudah serta panduan yang jelas, sangat dibutuhkan bagi masyarakat awam, sehubungan dengan beragamnya latar belakang mereka. Khususnya bagi kader posyandu lansia, orang yang berperan sebagai 
kader di sini sifatnya adalah sukarelawan, artinya siapa saja yang memang memiliki kemauan untuk mengabdi sebagai kader diperbolehkan untuk bergabung, tanpa dibatasi dengan kriteria seperti latar belakang pendidikan yang harus tinggi atau latar belakang kesehatan. Kader posyandu lansia memiliki peranan penting sebagai penyambung program-program pemerintah pada tatanan kelompok masyarakat. Salah satu tujuan pembangunan kesehatan pada masyarakat lanjut usia adalah meningkatkan kesejahteraan dan termasuk kesehatan, untuk mencapai tujuan program tersebut dibutuhkan peranan kader posyandu lansia sebagai penggerak masyarakat, pemantauan dan pelatihan.

Tidak sedikit kader posyandu lansia yang telah menjalani peran sebagai kader dalam kurun waktu hingga belasan maupun puluhan tahun, yang artinya usia kader pun akan semakin variasi, dan cenderung usianya dewasa akhir. Pada kelompok demikian, pembelajaran sebuah materi harus disesuaikan agar tidak memberatkan dan lebih menitikberatkan pada pemberian contoh langsung agar para kader juga bisa menerapkan dengan mudah. Untuk itu, konsep pembelajaran orang dewasa bisa diterapkan dengan metode pelatihan, diskusi kelompok kecil dan bermain peran agar dapat memberikan gambaran nyata dari materi yang diberikan (Zainiah \& Suratini, 2014).

Penelitian ini mencoba memberikan solusi dengan skala stroke KEM-WATABI, yang merupakan akronim dari keseimbangan, mata (lapang pandang), wajah (simetris), tangan (kemampuan otot) dan bicara (gangguan bicara). Skala ini melengkapi kekurangan pada alat ukur yang telah disebutkan sebelumnya di atas. Perbedaan skala ini dengan yang telah ada adalah adanya penambahan indikator keseimbangan dan lapang pandang mata, yang masih belum ada di skala FAST. Skala KEM-WATABI juga dilengkapi dengan langkahlangkah pemeriksaan dan pencacatan yang belum ada pada slogan Segera Ke RS. Skala stroke KEM-WATABI ini merupakan skala baru yang dibuat untuk memudahkan masyarakat awam dalam melakukan skrining stroke secara mandiri.

\section{RUANG LINGKUP}

Penelitian mencakup permasalahan terkait penyakit neurologi pada lanjut usia, yaitu manajemen stroke pada fase pre hospital. Bagaimana orang di sekitar lansia yang berisikan mengalami stroke dapat ikut melakukan pencegahan terhadap angka kecacatan dan angka kematian akibat stroke. Komponen manajemen stroke fase pre hospital cukup luas, oleh karena itu dalam penelitian ini batasan masalah dalam penelitian ini adalah pengenalan tanda dan gejala stroke menggunakan skala KEM-WATABI, yang dilakukan oleh kader posyandu lansia sebagai bagian dari masyarakat yang memiliki program dan kedekatan pada kelompok lansia yang be-risiko terkena stroke.

Berdasarkan latar belakang yang telah dipaparkan, maka rumusan masalah dalam penelitian ini adalah:
Apakah terdapat pengaruh skala KEM-WATABI terhadap kemampuan skrining stroke pada kader posyandu lansia? Pengenalan tanda dan gejala stroke bagi masyarakat terutama orang-orang di sekitar lansia dengan risiko stroke sangat penting untuk membantu pasien dalam mendapatkan pertolongan segera, sehingga tanda dan gejala stroke dapat dicegah. Mengganti sikap dan perilaku masyarakat memang tidak mudah, diperlukan peranan berbagai pihak yang dapat dipercaya atau mampu mempengaruhi masyarakat untuk mau berubah. Salah satu pihak yang dapat dilibatkan adalah kader posyandu lansia yang memiliki program terstruktur dalam melakukan bina kesehatan lansia. Kader posyandu yang berasal dari bagian masyarakat mempunyai kelebihan secara kedekatan emosional sehingga dapat secara langsung membimbing lansia untuk mencapai derajat kesehatan se optimal mungkin terhadap terjadinya serangan stroke. Oleh karena itu, kader posyandu lansia perlu dibekali dengan keterampilan dan pengalaman terkait skrining indikator stroke.

Berdasarkan paparan diatas, batasan masalah yang ditetapkan dalam penelitian ini adalah untuk mengetahui pengaruh pelatihan skala KEM-WATABI terhadap kemampuan psychomotor skrining stroke pada kader posyandu lansia. Hasil penelitian ini akan membantu kader posyandu lansia untuk meningkatkan kemampuan secara psychomotor, dalam melakukan skrining tanda dan gejala stroke.

\section{BAHAN DAN METODE}

Penelitian ini menggunakan desain pre eksperimental dengan pendekatan one group pre-post-test design. Variabel yang diteliti adalah kemampuan psychomotor dalam melakukan skrining tanda dan gejala stroke menggunakan skala KEM-WATABI.

Populasi penelitian ini adalah kader posyandu lansia sebanyak 24 orang. Subjek penelitian berjumlah 16 kader lansia yang diperoleh dengan menggunakan teknik purposive sampling. Subjek dalam penelitian ini adalah kader posyandu lansia Desa Darungan, Kecamatan Pare, berusia 20-40 tahun, sudah menjadi kader lansia lebih dari 4 bulan, masih aktif dalam kegiatan lansia, tidak sedang sakit, tidak ikut dalam tracing covid-19, dan mampu membaca dan menulis.

Karakteristik subjek dalam penelitian ini diklasifikasikan berdasarkan usia 20-30 tahun dan 31-40 tahun, karakteristik pendidikan diklasifikasikan menjadi tidak sekolah, tamat SD, tamat SMP, tamat SMA dan tamat perguruan tinggi. Karakteristik berikutnya adalah lama menjadi kader yang dikategorikan berdasarkan waktu keikutsertaan menjadi kader kurang dari 6 bulan, 6 bulan sampai 1 tahun, dan lebih dari 1 tahun. Karakteristik selanjutnya adalah pernah atau tidak mendapatkan pelatihan tentang pengkajian dan menemui atau melakukan pengkajian stroke di masyarakat

Selama penelitian subjek diberikan pelatihan tentang penggunaan skala KEM-WATABI untuk membahas tanda dan gejala stroke. Subjek diberikan materi tentang 
skrining tanda dan gejala stroke sesuai indikator pemeriksaan yaitu keseimbangan, lapang pandang mata, simetris wajah, kekuatan otot tangan, dan kemampuan bicara (KEM-WATABI). Langkah-langkah skrining stroke dalam skala KEM-WATABI yang dilakukan oleh kader posyandu lansia adalah sebagai berikut:

a. Skrining keseimbangan terdiri dari 5 langka, yaitu 1) meminta penderita untuk berdiri dan memilih kaki terkuat, 2) meminta penderita mengangkat salah satu kakinya yang mengalami kelemahan, 3) meminta pasien menahan kaki yang diangkat sekitar 20 detik, dengan mata tertutup, 4) mengamati adanya kaki yang bergerak turun selama periode mengangkat kaki dan 5) menyimpulkan ada atau tidaknya gangguan keseimbangan.

b. Skrining lapang pandang mata terdiri dari 8 langkah, yaitu 1) berdiri atau posisi di depan dan di samping penderita, 2) menanyakan kepada penderita, apakah penderita dapat melihat posisi kader, 3) meminta pasien untuk menutup salah satu mata yang tidak di tes, 4) meminta penderita untuk melihat ke atas, 5) meminta penderita untuk melihat ke bawah, 6) meminta penderita untuk melihat ke samping dalam, 7) meminta penderita untuk melihat ke samping luar, 8) mengidentifikasi kemampuan lapang pandang penderita untuk masing-masing mata.

c. Skrining simetris wajah terdiri dari 4 langkah, yaitu 1) meminta penderita memperlihatkan giginya atau tersenyum, 2) mengamati ketidak simetris antara sisi kanan dan sisi kiri pada wajah pasien, 3) mengamati adanya sudut bibir yang hanya mengangkat salah satu sisi, 4) menyimpulkan adanya kelemahan otot pada salah satu sisi wajah.

d. Skrining kekuatan otot tangan terdiri dari 5 langkah, yaitu 1) meminta pasien mengangkat kedua lengannya, 2) meminta pasien menahan kedua lengannya lurus ke depan sekitar 10 detik, dengan mata tertutup, 3) mengamati adanya salah satu sisi lengan bergerak turun, 4) mengamati adanya lengan yang tidak bisa digerakkan sama sekali, 5) menyimpulkan adanya kelemahan otot pada salah satu sisi tubuh.

e. Skrining kemampuan bicara terdiri dari 5 langkah, yaitu 1) meminta pasien mengucapkan kata atau kalimat tertentu, 2) mengamati apakah pasien mengucapkan kalimat dengan jelas, 3) mengamati adanya kesulitan berbicara pada pasien, 4) Mengamati adanya kelemahan pada lidah, 5) menyimpulkan adanya gangguan pada kemampuan bicara pasien.

Peneliti akan mengamati langkah-langkah yang dilakukan oleh subjek dan menandai opsi pada lembar observasi "ya" untuk tindakan yang dilakukan dan opsi "tidak" untuk tindakan yang dilakukan. Setiap tindakan yang dilakukan diberikan nilai 1 dan tidak dilakukan di berikan nilai 0 . Skor maksimal dari lembar observasi adalah 27 poin, poin penilaian kemudian dikonversi ke dalam bentuk nilai persentase, kemudian dianalisis dengan metode deskriptif kuantitatif, lalu mengategorikan tingkat kemampuan kader dalam tiga tingkatan (tabel 1).

Tabel 1. Kategori Tingkat Kemampuan Skrining

\begin{tabular}{ccc}
\hline Skor Observasi & $\begin{array}{c}\text { Persentase } \\
(\%)\end{array}$ & Kemampuan \\
\hline $20,52-27$ & $76-100$ & Mampu \\
$15,12-20,25$ & $56-75$ & Cukup mampu \\
$0-15$ & $0-56$ & Tidak mampu \\
\hline
\end{tabular}

Langkah selanjutnya adalah menentukan adanya pengaruh pelatihan terhadap kemampuan psychomotor kader dengan melakukan uji statistik pada nilai observasi menggunakan program SPSS dengan Wilcoxon signed rank-test.

\section{HASIL DAN PEMBAHASAN}

Hasil penelitian ini disajikan dalam 3 bagian, yaitu data demografi, perbedaan tingkat kemampuan skrining kader, dan pengaruh skala KEM-WATABI terhadap kemampuan skrining kader posyandu lansia.

\subsection{Data Demografi}

Data demografi pada penelitian ini meliputi karakteristik subjek yang meliputi usia, pendidikan, lama menjadi kader, riwayat pelatihan pengkajian stroke. Data disajikan pada Tabel 2.

Berdasarkan hasil tabel 2 didapatkan bahwa sebagian besar (75\%) subjek dalam penelitian ini memiliki rentang usia antara 31-40 tahun. Sesuai dengan karakteristik pendidikan setengah dari subjek $(50 \%)$ memiliki riwayat pendidikan tamat SMP/sederajat, dengan periode lama menjadi kader sebagian besar $(56,2 \%)$ sudah lebih dari 12 bulan. Berdasarkan karakteristik riwayat pengalaman seluruh subjek $(100 \%)$ pernah mendapatkan pelatihan pengkajian stroke, namun sebagian besar $(81,2 \%)$ subjek belum pernah menjumpai maupun melakukan pengkajian stroke secara langsung baik di masyarakat maupun di keluarga. 
Keterampilan dan produktivitas seseorang, dapat berbanding terbalik dengan peningkatan usia setelah melewati usia dewasa. Hasil penelitian (Nurayu, 2013) mengemukakan bahwa 17 dari 25 kader yang berusia tua ( $\geq 36$ tahun) memiliki kualitas laporan kegiatan yang kurang baik, namun dalam perspektif lain, semakin tua usia, maka akan semakin tinggi pengalaman dan kematangan dalam hal ini dapat meningkatkan kepercayaan masyarakat terhadap kader dan pengelolaan posyandu. Kader posyandu dengan kategori usia muda sebagian besar tidak aktif kehadirannya dalam pengelolaan posyandu dibandingkan dengan kader dengan kategori usia tua, hal ini dihubungkan dengan rutinitas harian seperti urusan rumah tangga, mengasuh anak, pekerjaan dan lain sebagainya (Banowati, 2020).

Latar belakang pendidikan seseorang, dalam hal ini kader posyandu lansia, merupakan salah satu faktor yang mempengaruhi kinerjanya, menurut Schermerchorn JR (Sukandar $d k k$., 2019). Fakta penelitian menampilkan bahwa separuh subjek berpendidikan dasar menengah pertama, tingkatan ini merupakan capaian yang sesuai dengan program pemerintah menurut aturan pendidikan dasar, sehingga kader dapat dianggap mampu untuk menjalankan peran dan fungsinya dalam pelaksanaan program posyandu lansia.

Periode keanggotaan dari kader posyandu lansia umumnya tidak terbatas waktu, selama yang bersangkutan masih berkenan maka keanggotaan masih tetap berjalan, karena sifat dari kader ini adalah sukarela. Semakin lama waktu menjadi kader dapat memberikan pengalaman tersendiri untuk mengenal berbagai aspek pelayanan dalam posyandu lansia, seperti melaksanakan tugas dan fungsi, melakukan mobilisasi, memberikan edukasi dan meningkatkan kepercayaan masyarakat. Riwayat lamanya waktu menjadi kader dapat berkontribusi terhadap keterampilan kader, semakin lama menjadi kader akan semakin baik dalam melakukan perannya sebagai kader.

\subsection{Perbedaan Tingkat Kemampuan Skrining Kader}

Pengukuran kemampuan subjek dilakukan dua tahap, tahap pertama adalah sebelum intervensi dilakukan, dan tahap kedua adalah setelah satu hari intervensi selesai dilakukan.

Berdasarkan pada tabel 3 didapatkan bahwa seluruh subjek (100\%) tidak mampu melakukan skrining stroke menggunakan skala KEM-WATABI pada ambilan data pre-test, sedangkan hasil post-test nya menunjukkan sebagian besar responden $(81,3 \%)$ mampu melakukan skrining stroke menggunakan skala KEM-WATABI. Kemampuan yang diamati dalam penelitian ini merupakan kemampuan psychomotor dari kader dalam melakukan skrining stroke. Selain aspek kognitif dan afektif, aspek psychomotor juga penting untuk diperhatikan dan ditingkatkan, guna meningkatkan keterampilan kader dalam melakukan pelayanan di posyandu (Hendrawati, 2018).

Keterangan: $\mathrm{F}=$ Frekuensi, $\%=$ persentase
Tabel 2. Karakteristik Subjek

\begin{tabular}{|c|c|c|c|}
\hline No & Kategori & $\mathrm{F}$ & $\%$ \\
\hline \multirow[t]{3}{*}{1} & Usia (Tahun) & & \\
\hline & $20-30$ & 4 & 25 \\
\hline & $31-40$ & 12 & 75 \\
\hline \multirow[t]{4}{*}{2} & Pendidikan & & \\
\hline & $\mathrm{SD} /$ Sederajat & 3 & 18,8 \\
\hline & SMP/Sederajat & 8 & 50 \\
\hline & SMA/Sederajat & 5 & 31,2 \\
\hline \multirow[t]{4}{*}{3} & $\begin{array}{l}\text { Lama Menjadi Kader } \\
\text { (Bulan) }\end{array}$ & & \\
\hline & $4-7$ & 1 & 6,2 \\
\hline & $8-12$ & 6 & 37,5 \\
\hline & $>12$ & 9 & 56,2 \\
\hline \multirow[t]{3}{*}{4} & $\begin{array}{l}\text { Pernah Pelatihan } \\
\text { Pengkajian Stroke }\end{array}$ & & \\
\hline & Iya & 16 & 100 \\
\hline & Tidak & 0 & 0 \\
\hline \multirow[t]{3}{*}{5} & $\begin{array}{l}\text { Pernah Menjumpai cara } \\
\text { Pengkajian Stroke }\end{array}$ & & \\
\hline & Iya & 3 & 18,8 \\
\hline & Tidak & 13 & 81,2 \\
\hline
\end{tabular}

Merujuk hasil pre-test yang tersaji pada tabel 3, peneliti melakukan analisis lebih lanjut pada rekapitulasi data penelitian. Rerata skor observasi kemampuan skrining stroke subjek pre-test adalah 7,93, sesuai dengan konversi kategori kemampuan skrining pada tabel 1, rata-rata skor ini dikategorikan dalam kriteria tidak mampu. Hasil kemampuan skrining pre-test ini menjadi bertolak belakang apabila dihubungkan dengan riwayat subjek yang sebagian besar telah memiliki riwayat mengikuti pelatihan pengkajian stroke sebelumnya.

Tabel 3. Tingkat kemampuan skrining subjek pre-test

\begin{tabular}{llcccc}
\multicolumn{7}{c}{ - post test } \\
\hline \multirow{2}{*}{ No. } & Kemampuan & \multicolumn{2}{c}{ Pre test } & Post test \\
\cline { 2 - 6 } & Skrining stroke & F & \% & F & $\%$ \\
\hline \multirow{2}{*}{1} & Mampu & 0 & 0 & 13 & 81,3 \\
2 & Cukup Mampu & 0 & 0 & 3 & 0 \\
3 & Tidak Mampu & 16 & 100 & 0 & 0 \\
\hline & Jumlah & 16 & 100 & 16 & 100 \\
\hline
\end{tabular}

Keterangan : $\mathrm{F}=$ Frekuensi, $\%=$ Persentase

Bahwa pengalaman mengikuti pelatihan dapat meningkatkan kemampuan kader posyandu. Namun, setelah dilakukan pemeriksaan pada isian data kuesioner, ketidakmampuan kader mayoritas berada pada indikator deteksi keseimbangan dan deteksi lapang pandang mata. Pada materi kedua indikator tersebut, belum diajarkan dalam pelatihan pengkajian stroke yang diikuti oleh subjek sebelumnya, yaitu menggunakan skala FAST. Skor hasil observasi pre-test pada kedua indikator tersebut rata-rata adalah 0 , atau tidak melakukan. Selain itu, item jabaran tindakan yang harus dilakukan pada kedua indikator tersebut terdapat 12 jenis, yang artinya menyusun hampir separuh dari total skor lembar observasi yang mencapai skor 27. Oleh karena itu, wajar 
apabila kader tidak mampu melakukan pada kedua indikator tersebut, maka nilai skor yang didapatkan berkurang secara drastis hingga kriteria tidak mampu (Sukandar, $d k k$., 2019).

Sementara, apabila dilihat skor pada lembar observasi kemampuan kader dalam melakukan skrining tanda stroke dalam indikator deteksi simetris wajah, deteksi kemampuan mengangkat tangan dan deteksi kesulitan bicara, rata-rata skor nya adalah 1 yang artinya subjek melakukan tindakan saat observasi. Pada materi ketiga indikator ini subjek mendapatkan materi yang sama dengan pelatihan yang pernah diikuti sebelumnya.

Hasil penelitian yang disajikan dalam tabel 3 terkait kemampuan skrining post-test, kemampuan subjek dalam melakukan skrining dini stroke mengalami peningkatan, yaitu sebagian besar subjek mampu dalam melakukan skrining dini stroke. Fakta ini mendukung beberapa penelitian sebelumnya terkait peningkatan keterampilan kader posyandu melalui metode pelatihan (Mardiana, 2011) dengan menggunakan pendekatan praktik sehingga kader mempunyai pengalaman langsung. Belajar berdasarkan masalah atau praktik langsung membuat peserta belajar tertarik untuk mengikuti kegiatan, dibandingkan dengan menggunakan metode konvensional yang dapat membuat peserta menjadi tergantung kepada pelatihnya.

Peningkatan kemampuan psychomotor kader dilakukan dalam 6 sesi latihan, yaitu sesi 1 yang dilakukan dengan penjelasan tujuan kegiatan, kemudian dilanjutkan pada sesi 2 dan 3 , yaitu pemberian materi dan diskusi dalam pembagian grup. Tahapan berikutnya adalah sesi 4-6 dilakukan simulasi dan praktikum/demonstrasi skrining dini stroke pada lansia. Berdasarkan hasil penelitian dari (Hendrawati $d k k$., 2018) melaporkan bahwa metode pelatihan seperti ini dinilai efektif dalam meningkatkan kemampuan psychomotor karena kader memiliki kesempatan untuk melakukan tindakan secara langsung berdasarkan materi, dan dipandu dengan modul sehingga kader memahami apa yang harus dilakukan untuk setiap indikator yang dikaji. Metode pembelajaran menggunakan metode simulasi dan demonstrasi efektif terhadap pelaksanaan kegiatan dari materi yang diajarkan (Indri $d k k$., 2017).

\subsection{Pengaruh Skala KEM-WATABI Terhadap Kemampuan Skrining Kader Posyandu Lansia.}

Kemampuan skrining stroke dibagi menjadi kategori mampu, cukup mampu dan tidak mampu. Data pengaruh pelatihan skala KEM-WATABI terhadap kemampuan skrining kader posyandu lansia disajikan pada tabel 4 .

Berdasarkan hasil uji pada tabel 4 terdapat pengaruh yang sangat signifikan pelatihan skala KEM-WATABI terhadap peningkatan kemampuan kader posyandu lansia $(\mathrm{p}=0,000)$. Analisis peneliti terkait peningkatan kemampuan ini secara spesifik terjadi pada kemampuan melakukan skrining stroke pada indikator keseimbangan dan lapang pandang. Meskipun pada indikator lain pun juga terdapat perubahan, namun perubahan skor nya tidak terlalu signifikan. Munculnya peningkatan kemampuan ini akibat adanya penguatan dan stimulus yang diberikan selama menjalani sesi pelatihan, terdapatnya petunjuk langkah-langkah skrining yang dapat dipahami oleh subjek. Metode pelatihan yang juga melibatkan probandus (lansia yang berperan sebagai pasien) untuk dapat di skrining secara langsung, memberikan pengalaman secara langsung bagi subjek sehingga pemahaman lebih kuat dan mudah untuk diingat (Indri $d k k .$, 2017).

Tabel 4. Analisis pengaruh pelatihan skala KEMWATABI terhadap kemampuan skrining kader posyandu lansia

\begin{tabular}{|c|c|c|c|c|c|}
\hline \multirow{2}{*}{ Kategori } & \multicolumn{2}{|c|}{ Pre test } & \multicolumn{2}{|c|}{ Post test } & \multirow[b]{2}{*}{$\mathbf{p}$} \\
\hline & $\mathbf{F}$ & $\%$ & $\mathbf{F}$ & $\%$ & \\
\hline Mampu & 0 & 0 & 13 & 81,3 & \\
\hline Cukup & 0 & 0 & 3 & 18,7 & 0,000 \\
\hline Mampu & & & & & \\
\hline Tidak Mampu & 16 & 100 & 0 & 0 & \\
\hline Jumlah & 16 & 100 & 16 & 100 & \\
\hline
\end{tabular}

Keterangan: $\mathrm{F}=$ Frekuensi, $\%=$ Persentase, $\mathrm{p}=$ Nilai signifikansi

Selain faktor metode pembelajaran, peranan karakteristik subjek juga dapat menjadi faktor peningkatan kemampuan psychomotor yang diamati. Usia subjek penelitian ini tergolong usia produktif yaitu pada usia 30-40 tahun, dimana usia ini termasuk dalam kriteria dewasa sehingga kader dapat menyesuaikan diri dengan baik (Swandari dkk., 2017). Sesuai dengan tingkat perkembangan pada usia dewasa di asumsikan kelompok usia ini memiliki kesiapan belajar yang matang, karena memiliki peran sebagai pekerja, orang tua, pemimpin atau anggota dari sebuah organisasi. Orang dewasa siap untuk belajar hal-hal yang mereka perlu ketahui untuk mengatasi situasi kehidupannya secara efektif. Pada prinsipnya pendidikan orang dewasa adalah menekankan pada kebutuhan mereka dan lebih banyak mengembangkan ranah afektif dan psychomotor; seperti keterampilan dan keahlian pada pekerjaanpekerjaan tertentu (Alfarabi, 2015).

Sesuai dengan hasil paparan data penelitian didapatkan bahwa separuh dari subjek penelitian ini memiliki riwayat pendidikan tamat $\mathrm{SMP} /$ sederajat. Merujuk pada klasifikasi jenjang pendidikan formal di Indonesia, tingkat pendidikan menengah pertama masuk dalam rangkaian pendidikan dasar yang wajib ditempuh.

Kader posyandu yang mempunyai pendidikan tinggi, tidak selalu menjadi kader yang terampil di posyandu, meskipun secara pengetahuan mereka baik tetapi mereka tidak menerapkan pengetahuannya dalam kegiatan atau pelaksanaan program di posyandu (Sutiani $d k k$., 2014).

Pengalaman atau lama waktu menjadi kader juga merupakan karakteristik yang dipertimbangkan untuk diketahui dalam penelitian ini. Hasil penelitian didapatkan bahwa Sebagian besar subjek telah menjadi kader dalam waktu lebih dari 12 bulan. Menurut hasil 
penelitian yang disajikan bahwa tidak ada hubungan yang signifikan antara lama masa menjadi kader posyandu dengan kemampuan dalam melakukan pengukuran kurva pertumbuhan balita (Syamsianah $d k k$., 2013). Namun pernyataan yang sedikit berbeda, dalam penelitiannya disebutkan bahwa kader yang sudah menjalani waktu lebih lama dari (Sutiani $d k k$., 2014)

5 tahun memiliki keterampilan yang lebih bagus dibandingkan dengan kader baru dalam hal pelaksanaan pemantauan pasien di posyandu, meskipun tidak disebutkan keterampilan apa yang membedakan secara spesifik. Oleh karena itu, semakin lama menjadi kader akan semakin banyak kasus yang ditangani sehingga semakin meningkat pengalamannya. Pengalaman lama bekerja memberikan peningkatan terhadap kemampuan dan keterampilan pelatihan terhadap kader.

Seluruh kader posyandu lansia dalam penelitian ini sebelumnya sudah pernah mendapatkan pelatihan tentang pengkajian tanda dan gejala stroke yang diberikan oleh petugas puskesmas dan juga oleh mahasiswa dari institusi Pendidikan Kesehatan yang menjalankan praktik di posyandu lansia desa Darungan. Tetapi materi yang didapatkan sebelumnya berbeda dengan skala KEMWATABI yang diberikan dalam penelitian ini. Perbedaan mendasarnya adalah pada indikator pemeriksaan Keseimbangan dan Lapang Pandang mata. Secara teori, pengalaman dari pelatihan sebelumnya dapat menunjang kemampuan kader untuk mengikuti pelatihan dalam penelitian ini, karena kader cukup mempelajari dari materi yang belum pernah didapatkan saja. Situasi ini memudahkan kader untuk mencerna materi lebih cepat. Hal ini dapat dibuktikan dengan hasil post-test yang baik meskipun dilakukan pengambilan pada satu hari setelah proses penelitian selesai.

\section{KESIMPULAN}

Terdapat pengaruh yang signifikan pelatihan skala stroke keseimbangan, mata, wajah, tangan dan bicara (KEM-WATABI) terhadap tingkat kemampuan psychomotor kader posyandu lansia dalam melakukan skrining stroke.

\section{SARAN}

Kader posyandu lansia hendaknya melakukan skrining secara periodik pada peserta posyandu lansia yang risiko mengalami stroke, sebagai sarana melatih kemampuan secara terus menerus agar semakin terampil dan sebagai upaya perbaikan manajemen stroke fase pre hospital.

\section{DAFTAR PUSTAKA}

Alfarabi, M., 2015. Konsep Pendidikan Orang Dewasa. UIN SU, Sumatra Utara.

Arif, M., Okraini, N., Mas, A.Y., 2019. Hubungan Ketepatan "GOLDEN PERIOD" Dengan Derajat Kerusakan Neurologi Pada Pasien Stroke Iskemik Diruang Instalasi Gawat Darurat Rumah Sakit
Stroke Nasional Bukittinggi Tahun 2018. Pros. Semin. Kesehat. Perintis E 2, 2622-2256.

Aroor, S., Singh, R., Goldstein, L.B., 2017. BE-FAST (Balance, Eyes, Face, Arm, Speech, Time): Reducing the Proportion of Strokes Missed Using the FAST Mnemonic. Stroke 48, 479-481.

Banowati, L., 2020. Hubungan Karakteristik Kader dengan Kehadiran dalam Pengelolaan Posyandu. J. Kesehatan. 9, 1179-1189.

Bariroh, U., Susanto, H. S., \& Adi, M. S. (2016). Kualitas hidup berdasarkan karakteristik pasien pasca stroke (studi di RSUD Tugurejo Kota Semarang). Jurnal Kesehatan Masyarakat (eJournal), 4(4), 486-495.

Hal Blumenfeld, 2010. Neuroanatomy through Clinical Cases, second Edition, 2nd ed. Sinauer Associates, Inc. Publishers, Massachusetts.

Hendrawati, S., 2018. Pemberdayaan Kader Kesehatan dalam Pencegahan dan Penatalaksanaan Stunting pada Anak di Wilayah Kerja Puskesmas Jatinangor. Dharmakarya 7, 274-279.

Hendrawati, S., Mardhiyah, A., Mediani, H.S., Nurhidayah, I., Mardiah, W., Adistie, F., Maryam, N.N.A., 2018. Pemberdayaan Kader Posyandu dalam Stimulasi Deteksi dan Intervensi Dini Tumbuh Kembang (SDIDTK) pada Anak Usia 0 6 Tahun di Desa Cileles Kecamatan Jatinangor Kabupaten Sumedang. Media Karya Kesehat. 1.

Howard, C., Rowe, F.J., 2018. Adaptation to poststroke visual field loss: A systematic review. Brain Behav. 8.

Indri, E., Tri, K., Aziz, A.H., 2017. Efektivitas Metode Simulasi dan Demontrasi Dalam Pelaksanaan. Jakarta.

Loomis, C., \& Mullen, M. (2014). Differentiating Facial Weakness Caused by Bell's Palsy vs. Acute Stroke; Can you tell the difference. Journal of Emergency Medical Services (JEMS), 39(5).

Mardiana, M. 2011. Pelatihan Terhadap Keterampilan Kader Posyandu. KEMAS: Jurnal Kesehatan Masyarakat, 7(1), 25327.

Mutiarasari, D., 2019. Ischemic Stroke: Symptoms, Risk Factors, and Prevention. J. Ilm. Kedokt. 6.

Nurayu, A.W., 2013. Hubungan Tingkat Pengetahuan, Pendidikan, Usia Dan Lama Menjadi Kader Posyandu Dengan Kualitas Laporan Bulanan Data Kegiatan Posyandu. J. Univ. Muhammadiyah Surakarta 1-17.

Ojaghihaghighi, S., Vahdati, S. S., Mikaeilpour, A., \& Ramouz, A. Comparison of neurological clinical manifestation in patient with hemorrhagic and ischemic stroke. World J Emerg Med. 2017; 8 (1): 34-8.Prabhakaran, S., Ruff, I., 2015. Acute Stoke Intervention: A Systematic Review. JAMA J. Am. Med. Assoc. 313, 1451-1462.

Rahman, R., Dewi, F. S. T., \& Setyopranoto, I. (2017). Dukungan keluarga dan kualitas hidup penderita stroke pada fase pasca akut di Wonogiri. Berita 
Kedokteran Masyarakat, 33(8), 383-390.

Rowe, F., 2016. Visual effects and rehabilitation after stroke. Community eye Heal. 29, 75-76.

Saengsuwan, J., Suangpho, P., Tiamkao, S., 2017. Knowledge of Stroke Risk Factors and Warning Signs in Patients with Recurrent Stroke or Recurrent Transient Ischaemic Attack in Thailand. Neurol. Res. Int. 2017.

Setianingsih, S., Darwati, L.E., Prasetya, H.A., 2019. STUDY DESKRIPTIF PENANGANAN PREHOSPITAL STROKE LIFE SUPPORT PADA KELUARGA. J. Perawat Indones. 3, 55.

Sukandar, H., Faiqoh, R., Effendi, J.S., 2018. Hubungan Karakteristik terhadap Tingkat Aktivitas Kader Posyandu Kecamatan Soreang Kabupaten Bandung, Jurnal Sistem Kesehatan.

Sutiani, R., Lubis, Z., Siagian, A., 2014. Description of Cadres Knowledge and Skills in Monitoring the Growth of Infant and Under Five Children in Puskesmas Desa Lalang 2014. Giz, Kesehat. reproduksi dan Epidemiol. 1, 1-8.

Syamsianah, A., \& Winaryati, E. (2013). Hubungan Pengetahuan dan Lama Kerja Dengan Ketrampilan Kader Dalam Menilai Kurva Pertumbuhan Balita di Posyandu Kelurahan Tegalsari Kecamatan Candisari Kota Semarang. Jurnal Gizi, 2(1).

Swandari, P., Handayani, O. W. K., \& Mukarromah, S. B. 2017. Karakteristik Ibu Dalam Pemberian Makanan Pendamping ASI (MPASI) Dini Terhadap Status Gizi Balita Usia 6-24 Bulan di Wilayah Kerja Puskesmas Umbulharjo I Kota Yogyakarta Tahun 2017. Public Health Perspective Journal, 2(3).

Tabara, Y., Okada, Y., Ohara, M., Uetani, E., Kido, T., Ochi, N., Nagai, T., Igase, M., Miki, T., Matsuda, F., Kohara, K., 2015. Association of postural instability with asymptomatic cerebrovascular damage and cognitive decline: The japan shimanami health promoting program study. Stroke $46,16-22$.

Wlassoff, V., 2015. The 20 Second Test for Stroke Risk | Brain Blogger [WWW Document]. URL https://brainblogger.com/2015/02/07/the-20second-test-for-stroke-risk/ (accessed 10.30.20).

Zainiah, N., Suratini, S., 2014. Hubungan Frekuensi Pelatihan yang Diikuti Kader dengan Tingkat Keterampilan Kader dalam Pelayanan Posyandu di Desa Nogotirto Sleman Gamping Yogyakarta Tahun 2014.

\section{UCAPAN TERIMA KASIH}

Penelitian ini dibiayai seluruhnya oleh dana hibah dari Kemendikbud, Kemeristekbrin 2020 dengan Nomor kontrak penelitian hibah PDP : 083/SP2H /LT/DRPM/2020;102/SP2H/LT-MONO/L17/2020. Melalui ini, kami juga menyampaikan rasa terima kasih dan apresiasi kepada lembaga-lembaga yang berperan dalam proses terlaksananya penelitian antara lain kepada pengelola posyandu lansia Desa Darungan yang telah memberikan waktu dan izin kepada kami dalam penelitian, kepada pimpinan Lembaga Penelitian dan Pengabdian Masyarkat (LPPM) dan segenap civitas akademika STIKES

Karya Husada Kediri, yang telah memberikan dukungan moral, sehingga kami dapat menyelesaikan program penelitian ini 